\title{
RANCANG BANGUN SISTEM PENERIMAAN PESERTA DIDIK BARU (PPDB) SECARA ONLINE PADA SMP IT BAITUN NUR PUNGGUR LAMPUNG TENGAH
}

\author{
Ni Putu Diah Puspitasari'), Mustika' ${ }^{2)}$, Arif Hidayat ${ }^{3)}$ \\ Program Studi IImu komputer, Fakultas IImu Komputer, \\ Universitas Muhammadiyah Metro
}

Jl. Gatot Subroto No.100, Yosodadi, Metro Timur, Kota Metro - Lampung

\begin{abstract}
Abstrak - SMP IT Baitun Nur Punggur Lampung Tengah merupakan salah satu yayasan pendidikan sekolah berbasis pesantren (BSP) dan berstatuskan swasta. Berdasarkan penelitian yang sudah dilakukan, informasi yang diperoleh adalah mayoritas siswa berasal dari masyarakat sekitar lokasi sekolah karena media langsung yang digunakan untuk membantu dalam proses merekrut siswa baru saat ini jenis informasinya yaitu dengan cara menggunakan spanduk dan brosur. Kelemahannya adalah calon peserta datang langsung ke sekolah untuk melakukan pendaftaran dan mengisi formulir peserta, maka akan membutuhkan waktu yang cukup lama. Tujuan dari penelitian yang dilakukan pada SMP IT Baitun Nur Punggur adalah merancang sistem penerimaan peserta didik baru (PPDB) pada SMP IT Baitun Nur Punggur Lampung Tengah. Metode penelitian yang digunakan oleh penulis terdiri dari dua bagian, yaitu metode berdasarkan jenis penelitian dan teknik pengumpulan data pengamatan, wawancara, dokumentasi dan studi kepustakaan. Sistem dirancang menggunakan pendekatan pemrograman terstruktur dan menggunakan metode pengembangan perangkat lunak Waterfall, dengan teknik pengujian sistem menggunakan teknik Black Box Testing dan Beta testing. Bahasa pemrograman yang digunakan adalah PHP, dengan database MySQL dan menggunakan Framework Laravel. Alat pengembangan sistem yang digunakan adalah flowchart, dfd, erd. Berdasarkan permasalahan tersebut, maka dirancang sebuah sistem penerimaan peserta didik baru (PPDB) sesuai dengan tujuan penelitian. Pada sistem penerimaan peserta didik baru (PPDB) tersebut memiliki kelebihan diantaranya, yaitu memiliki form pendaftaran secara online, informasi pendaftaran, menu mendownload dan upload berkas, informasi pembayaran via rekening bank dan daftar ulang, informasi rincian biaya serta pengumuman hasil seleksi lulus atau tidak lulus.
\end{abstract}

Kata Kunci: PPDB Online; Pengembangan Sistem PPDB; PPDB SMP IT Baitun, Nur Punggur Lampung Tengah

Abstract - IT Baitun NurJunior high school Punggur Central Lampung is one of the pesantren-based school education foundations and has private status. Based on the research that has been done, the information obtained is that most 
students come from the community around the school location because the direct media used to assist in recruiting new students currently uses banners and brochures. The disadvantage is that prospective participants come directly to the school to register and fill out participant forms. It will take quite a long time. The purpose of the research conducted at IT Baitun Nur Junior High SchoolPunggur was to design a new student admission system at IT Baitun Nur Junior High SchoolPunggur, Central Lampung. The research method used by the author consists of two parts, namely the method based on the type of research and data collection techniques of observation, interviews, documentation, and literature study. The system is designed using a structured programming approach and uses the Waterfall software development method, with system testing techniques using Black Box Testing and Beta testing techniques. The programming language used is PHP, with a MySQL database and using the Laravel Framework. The system development tools used are flowchart, dfd, erd. Based on these problems, a new student admission system was designed according to the research objectives. The new student admission system has advantages, including having an online registration form, registration information, menus for downloading and uploading files, payment information via bank accounts and re-registration, information on cost details, and announcements of passing or failing selection results.

Keywords: acceptance of new students Online; Development of new student admission system; acceptance of new students at ITBaitun NurJunior High SchoolPunggur, Central Lampung

\section{PENDAHULUAN}

SMP IT Baitun Nur, merupakan salah satu yayasan pendidikan Sekolah Berbasis Pesantren (SBP) dan berstatuskan swasta, beralamatkan di Jalan SMP Negeri 1 Punggur Lampung Tengah. Mayoritas siswa berasal dari masyarakat sekitar lokasi sekolah karena media langsung yang digunakan untuk membantu dalam proses merekrut siswa baru saat ini jenis informasinya adalah dengan cara menggunakan spanduk dan brosur. Berdasarkan wawancara yang telah dilakukan dengan salah satu pihak sekolah menjelaskan kelemahan dari sistem yang berjalan saat ini yaitu sistem penerimaan peserta didik baru (PPDB) bagi peminat calon siswa yang berada diluar wilayah atau lingkungan sekolah harus mencari informasi melalui orang yang dikenal dengan pihak sekolah atau pegawai yang bekerja di SMP IT Baitun Nur (informasi dari mulut ke mulut) dan melakukan registrasi pendaftaran tersebut dengan cara datang langsung ke sekolah dan akan menyulitkan juga pada masa pandemi seperti sekarang ini.

Berdasarkan kelemahan pada sistem yang berjalan saat ini dibutuhkan sistem untuk mempermudah proses pendaftaran calon siswa baru. Adapun Tujuan 
Penelitian ini adalah untuk merancang sistem penerimaan peserta didik baru (PPDB) secara online pada SMP IT Baitun Nur Punggur Lampung Tengah. Hasil penelitian yang serupa telah dilakukan oleh (Nur Rachman dan Molavi Arman, 2010) dengan judul "Rancang Bangun Aplikasi Penerimaan Peserta Didik Baru Sekolah Swasta Berbasis Web" yaitu merancang aplikasi penerimaan peserta didik baru (PPDB) di sekolah swasta secara daring. Dikarenakan ada kebijakan pendidikan dalam

\section{KAJIAN PUSTAKA DAN LANDASAN TEORI \\ Rancang Bangun}

Sutabri (dalam Sari, 2017: 83) menyimpulkan bahwa rancang adalah "kegiatan yang memiliki tujuan untuk mendesain sistem baru yang dapat menyelesaikan masalah - masalah yang dihadapi perusahaan yang diperoleh dari pemilihan alternatif sistem yang terbaik".

Pressman (dalam Sari, 2017: 83) menjelaskan bahwa bangun adalah "kegiatan menciptakan sistem baru maupun mengganti atau memperbaiki sistem yang telah ada baik secara keseluruhan maupun hanya sebagian".

\section{Sistem}

Jogiyanto (dalam Wibowo, dkk., 2015: 51) menjelaskan sistem adalah "Jaringan kerja dari prosedur _ prosedur yang saling berhubungan, berkumpul bersama sama untuk melakukan suatu masa darurat penyebaran virus corona ini, dan sekolah diminta untuk menyiapkan strategi dalam penerimaan peserta didik baru (PPDB) yang dimana tetap mengikuti protokol kesehatan untuk mencegah penyebaran Covid-19, termasuk mencegah kontak fisik secara langsung yang dilakukan oleh siswa maupun orang tua. Dengan hal tersebut aplikasi dirancang agar memudahkan para calon siswa untuk melakukan pendaftaran tanpa harus datang kesekolah.

kegiatan atau menyelesaikan suatu sasaran yang tertentu".

Tata Sutabri (2011: 6) menjelaskan bahwa sistem adalah "Sekelompok unsur yang erat hubungannya satu dengan yang lain, yang berfungsi bersama - sama untuk mencapai tujuan tertentu".

\section{Penerimaan Peserta Didik Baru (PPDB) Secara Online}

Ririn (dalam Nasser, et.al., 2017: 114) menyimpulkan bahwa Penerimaan Peserta Didik Baru (PPDB) Online adalah :

Merancang sebuah sistem untuk melakukan otomasi seleksi PPDB. Yang dimana maksud dari otomasi adalah mulai dari proses pendaftaran, proses seleksi hingga pengumuman hasil seleksi yang dilakukan secara online dan berbasis waktu nyata yang dapat dilakukan dimana saja dan kapan saja. 


\section{Framework Laravel}

Naista (dalam Ambriani dan Nurhidayat, 2010: 59) menjelaskan bahwa framework adalah :Suatu struktur konseptual dasar yang digunakan untuk memecahkan suatu masalah yang kompleks. Framework merupakan suatu wadah atau kerangka kerja dari sebuah website yang akan dibangun. Dengan demikian pada kerangka tersebut akan memiliki waktu lebih singkat dan memudahkan dalam melakukan pembuatan website maupun perbaikan. Banyak keuntungan yang didapatkan jika menggunakan framework dalam membangun sebuah website. Salah satu keuntungan tersebut adalah memberikan struktur yang baik dalam program yang dibuat karena framework memiliki library atau fungsi yang bisa langsung digunakan oleh pengguna. Selain itu, framework mempermudah dalam pengerjaan program secara tim karena dalam membangun website harus melakukan penyesuaian dengan gaya framework yang dipakai.

\section{Black Box Testing}

Pengujian yang dilakukan pada Black Box Testing merupakan tahap untuk menguji keberhasilan suatu program. Shalahuddin dan Rosa (2011: 18) menjelaskan bahwa Black box testing adalah : Untuk menguji perangkat lunak dari sudut pandang spesifikasi fungsional tanpa menguji desain dan kode program. Pengujian ini dimaksudkan untuk mengetahui apakah fungsi-fungsi, masukan, dan keluaran dari perangkat lunak sesuai dengan spesifikasi yang dibutuhkan. Pengujian kotak hitam dilakukan untuk membuat kasus uji yang bersifat mencoba semua fungsi dengan memakai perangkat lunak apakah sesuai dengan spesifikasi yang dibutuhkan oleh pengguna. Kasus uji yang dibuat untuk melakukan pengujian black box testing harus dibuat dengan kasus benar dan kasus salah.

\section{METODE}

SMP IT Baitun Nur Punggur lampung Tengah merupakan sekolah swasta berbasis pesantren (BSP) yang mayoritas siswanya adalah sekitar sekolah . teknik pengumpulan data yang dilakukan oleh penulis menggunakan beberapa teknik yaitu : Pengamatan (observasi), Wawancara (interview), Dokumentasi (documentation), Studi Pustaka. Dalam metode penulis menggunakan metode waterfall untuk proses perancangan sistem.

Rossa dan Shalahuddin (2010: 117) menyimpulkan bahwa Model SDLC air terjun (waterfall) adalah :

Sering juga disebut model sekuensial linier (sequential linear) atau alur hidup klasik (klasik lifecycle). Model air terjun menyediakan pendekatan alur hidup perangkat lunak secara sekuensial atau berurutan dimulai dari requirement, design, implementation (coding), verification dan maintenance. 


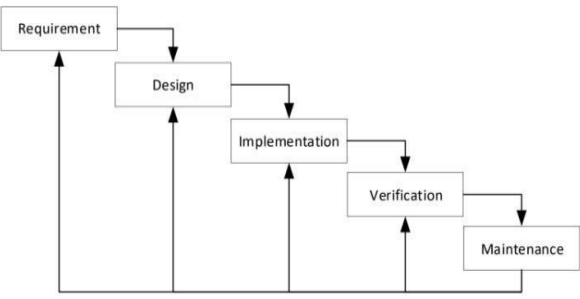

Gambar 1. Bagan Alur Metode Waterfall

\section{HASIL DAN PEMBAHASAN}

Rancang bangun sistem penerimaan peserta didik baru (PPDB) secara online pada SMP IT Baitun Nur Punggur Lampung Tengah yang dihasilkan dalam penelitian ini adalah dapat membantu dalam penerimaan peserta didik baru (PPDB).

\section{Relasi Tabel}

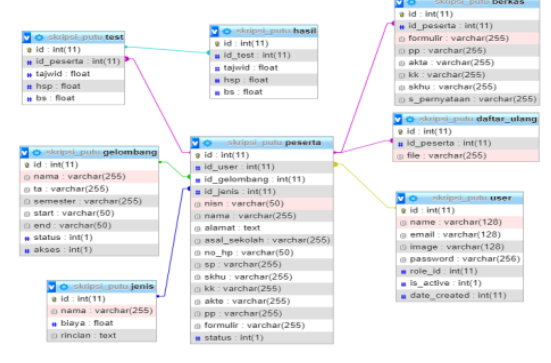

Gambar 2. Relasi Tabel

Gambar 2 merupakan gambar rancangan database sistem yang menggunakan relasi tabel. Terdapat 7 tabel yang saling berelasi yaitu tabel peserta, berkas, user, hasil, jenis, gelombang dan test.

\section{Tampilan Form Registrasi Akun Peserta}

Tampilan form registrasi akun akan terlihat oleh peserta yang akan mendaftar sebagai pengguna syarat untuk login PPDB sebelum menginputkan data diri beserta berkas. Berikut adalah Gambar 3.
Tampilan Form registrasi akun peserta.

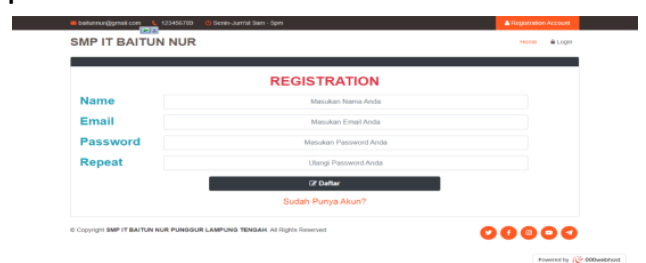

Gambar 3. Tampilan Form registrasi akun peserta.

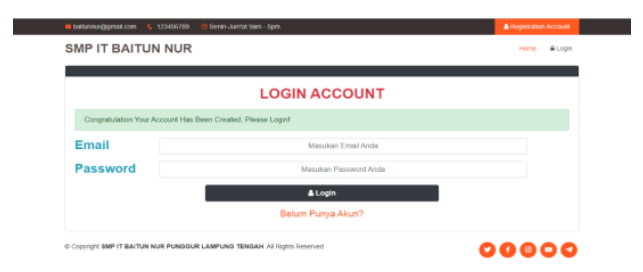

Gambar 4. Tampilan login user.

\section{Tampilan Input Data Peserta}

Peserta memasukkan data diri beserta berkas pendaftaran yang sudah disiapkan untuk dapat mendaftar di sekolah tersebut. Gambar 5. Tampilan input data peserta.

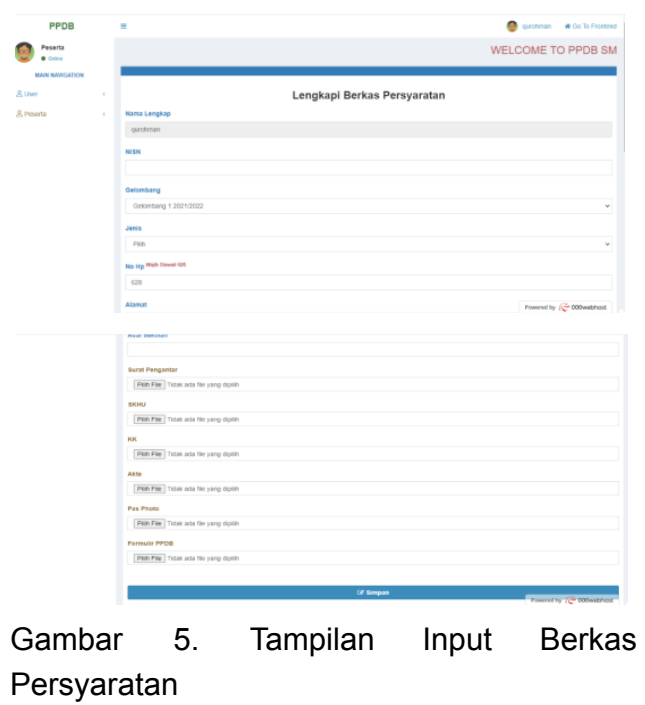

Tampilan Berkas Diterima atau Approved PPDB

Petugas tata usaha menerima berkas PPDB yang telah dikirim dari 
peserta pada saat mendaftar. Gambar 6. Tampilan Berkas Diterima atau Approved PPDB.

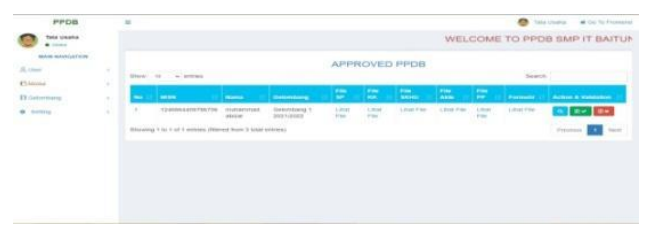

Gambar 6. Tampilan Approved PPDB.

\section{Tampilan Berkas Diterima}

Peserta mendapatkan notifikasi tes ketika berkas sudah divalidasi. Gambar 7. Tampilan Berkas Diterima.

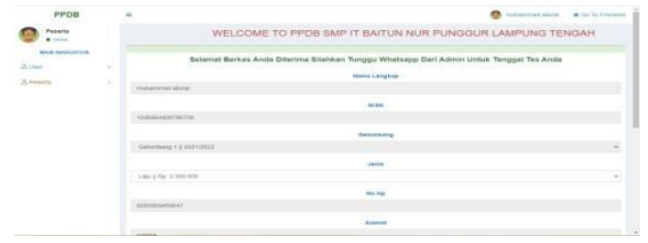

Gambar 7. Tampilan Berkas Diterima

\section{Tampilan Daftar Ulang}

Peserta melakukan daftar ulang ketika sudah diterima. Gambar 8. Tampilan Daftar Ulang.

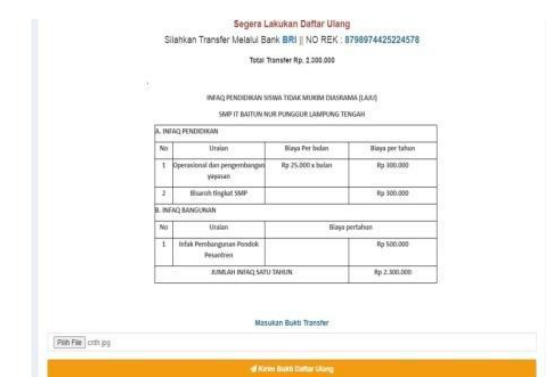

Gambar 8. Tampilan Daftar Ulang

\section{Tampilan Pengumuman Peserta}

Petugas tata usaha menginputkan pengumuman peserta secara kolektif di halaman utama. Gambar 9. Tampilan Pengumuman Peserta.

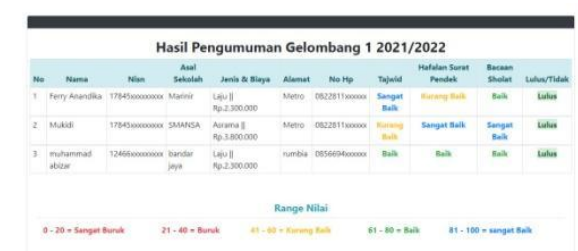

Gambar 9. Tampilan Pengumuman Peserta

1. Tampilan Upload Bukti Pembayaran

Sistem yang mampu mempermudah proses pembayaran melalui via rekening bank dan mengupload bukti pembayaran dan terdapat cek validasi bukti pembayaran dengan type data pdf, jpg dan jpeg.

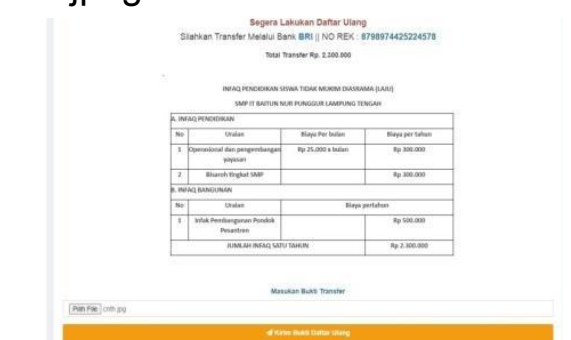

Gambar 10. Tampilan Upload Bukti Pembayaran

\section{KESIMPULAN}

Setelah melakukan riset penelitian yang dilaksanakan pada SMP IT Baitun Nur Punggur Lampung Tengah pada tanggal 01 Desember hingga 15 Desember 2020, dengan menggunakan metode Waterfall dan sudah melakukan pengujian dengan menggunakan Black Box Testing dan Beta Testing penulis menarik kesimpulan bahwa proses PPDB pada saat sebelum pandemi Covid-19 masih dilakukan secara langsung datang ke sekolah untuk mencari informasi dan cara pendaftaran PPDB.

Berdasarkan wawancara dengan pihak SMP IT Baitun Nur Punggur 
Lampung Tengah terdapat kelemahan pada saat melakukan PPDB secara langsung seperti peserta harus datang kesekolah karena informasi yang begitu terbatas, melakukan pendaftaran secara langsung, pengisian formulir, pengumpulan berkas, tes peserta, dan daftar ulang dilakukan secara langsung. Sehingga dapat menyulitkan peserta yang mendaftar di luar daerah tersebut.

Tujuan dari penelitian ini sudah tercapai yang dimana telah menghasilkan sebuah website penerimaan peserta didik baru (PPDB) sesuai dengan tujuan dari riset penelitian ini yaitu rancang bangun sistem penerimaan peserta didik baru (PPDB) secara online pada SMP IT Baitun Nur Punggur Lampung Tengah.

Pada website penerimaan peserta didik baru (PPDB) yang telah dirancang oleh penulis ini, terdapat beberapa kelebihan yang bermanfaat bagi panitia pendaftaran. Kelebihan dan manfaat tersebut antara lain yaitu dengan tersedianya:

a. Form pendaftaran, sistem yang mempermudah dalam proses penginputan data pendaftaran calon siswa baru untuk mendaftar sekolah.

b. Sistem yang mampu memberikan informasi pendaftaran sehingga informasi menjadi luas.

c. Menu mendownload dan upload berkas, yang mempermudah dalam melengkapi berkas-berkas persyaratan pendaftaran. d. Informasi pembayaran via rekening bank,yang mempermudah calon peserta untuk melakukan daftar ulang.

e. Informasi Rincian biaya dan pengumuman tes, yang mempermudah calon siswa mendapatkan informasi rincian dan pengumuman hasil seleksi.

Saran Untuk penulis adalah Rancang Bangun Sistem Penerimaan Peserta Didik Baru (PPDB) Secara Online Pada SMP IT Baitun Nur Punggur Lampung tengah yang telah dirancang oleh penulis ini tentunya memiliki kekurangan. Kekurangan tersebut antara lain penerimaan peserta didik baru yang dirancang oleh penulis ini belum lengkap fitur tes secara online dan daftar ulang, disarankan kepada peneliti selanjutnya untuk dapat merancang website penerimaan peserta didik baru (PPDB) yang bisa melengkapi fitur-fitur yang lengkap dan menarik.

\section{DAFTAR PUSTAKA}

[1] Adiputra, A. R., Karsidi, R., \& Haryono, B. (2019). Cultural Lag Dalam Program Penerimaan Peserta Didik Baru (PPDB) Online Dengan Sistem Zonasi Tahun 2018 Di Sekolah Menengah Atas Negeri 2 Sukoharjo. Habitus: Jurnal Pendidikan, Sosiologi, Dan Antropologi, 3(1), 1-13. https://jurnal.uns.ac.id/habitus/issu e/view/2364 
[2] Ambriani, D. (2020). Rancang Bangun Repository Publikasi IImiah Dosen Berbasis Web Menggunakan Framework Laravel. Jurnal Manajemen

[3] Ansar, N. R. (2019). Implementasi Manajemen Penerimaan Peserta Didik Baru Berbasis Online di SMK Negeri 6 Makassar. Jurnal Dinamika Manajemen Pendidikan, 4(1), 65. https://doi.org/10.26740/jdmp.v4n1. p65-72k

[4] Eviani Susana , Rizki Syafrika Deni, P. M. (2016). Sistem Informasi Penerimaan Siswa Baru Berbasis Web Pada Smpn 34 Kabupaten Tebo. Universitas Putra Indonesia YPTK Padang, 1, 1-7.

[5] Fajriyah, F., Josi, A., \& Fisika, T. (2017). Rancang Bangun Sistem Informasi Tender Karet Desa Jungai Menggunakan Metode Waterfall. Jurnal Sisfokom (Sistem Informasi Dan Komputer), 6(2), 111.

https://doi.org/10.32736/sisfokom.v $\underline{6 i 2.256}$

[6] Irfiani, E., \& Encep, M. (2017). Rancang Bangun Sistem Informasi Penerimaan Peserta Didik Baru Berbasis Web (Studi Kasus: Smp Amaliah Bogor). Swabumi, 5(1), 10-16.

http://ejournal.bsi.ac.id/ejurnal/inde x.php/swabumi/article/view/1757/12 $\underline{98}$

[7] Jaya, T. S., \& Sahlinal, D. (2017). Perancangan Kantor Digital
Berbasis Framework dengan Metode Waterfall pada Politeknik Negeri Lampung. Jurnal Pengembangan IT, 02(02), 14-17. http://ejournal.poltektegal.ac.id/inde x.php/informatika/article/view/518/5 $\underline{55}$

[8] Kasmi. (2013). Sistem Informasi Penerimaan Siswa Baru Berbasis Web pada SMA Darma Bangsa Bandar Lampung. Jurnal TAM ( Technology Acceptance Model ), 1(1), 41-50.

[9] Linatu Zahro, 2015, Skripsi Integrasi Iman dan IImu Pengetahuan dalam pendidikan Islam Kajian Q.S. Al Mujadalah Ayat 11, Q.S. Al Taubah Ayat 122, dan Q.S. Al Isra 36, Semarang: UIN Wali Songo.

[10] Luthfi, F. (2017). Penggunaan Framework Laravel Dalam Rancang Bangun Modul Backend Artikel Website Bisnis Bisnis.ID. JISKA (Jurnal Informatika Sunan Kalijaga), 2(1), 34. https://doi.org/10.14421/jiska.2017. 21-05

[11] Luthfi, F. (2017). Penggunaan Framework Laravel Dalam Rancang Bangun Modul Backend Artikel Website Bisnis Bisnis.ID. JISKA (Jurnal Informatika Sunan Kalijaga), 2(1),34. https://doi.org/10.14421/jiska.2017. $\underline{21-05}$

[12] Model, P., Manajemen, O., Kerja, M., \& Emiten, P. (2016). 
Universitas Muhammadiyah Metro. 42445(116), 42454.

[13] Nasser, R., Saputra, S., \& Syarif, U. (2017). Rancang Bangun Sistem Informasi Penerimaan Siswa Baru pada SMK Negeri 7 Palopo. Prosiding SEMANTIK 2017, 224-235.

[14] Ningtyas, D. A., Badrul, M., \& Sulistyowati, D. N. (2018). Sistem Informasi Penerimaan Peserta
Didik Baru Pada Smp Ar-Ridha Jakarta. Techno Nusa Mandiri, Vol 15(1), No.

1. http://ejournal.nusamandiri.ac.id/eju pdfrnal/index.php/techno/article/vie w/744l

[15] Nofiani, D. (2019). Administrasi Keuangan.

https://doi.org/10.31227/osf.io/tyhe 5 Data Manajemen Dan Teknologi Informasi. (2015). 16(4). 